\title{
Melanoma of the Iris pT1 TNM Finding v7
}

National Cancer Institute

\section{Source}

National Cancer Institute. Melanoma of the Iris pT1 TNM Finding v7. NCI Thesaurus.

Code C88672.

Melanoma of the iris with tumor limited to the iris. (from AJCC 7th Ed.) 